\title{
ISLAM LIBERAL DAN ANCAMAN TERHADAP PEMIKIRAN AHL SUNAH WALJAMAAH
}

\author{
H. A. Kadir Sobur \\ Fakultas Ushuluddin IAIN Sulthan Thaha Saifuddin Jambi \\ Jl. Arif Rahman Hakim Telanaipura, Jambi, 36124 \\ e-mai: muhamad_koni@yahoo.com
}

\begin{abstract}
Abstrak: Tulisan ini berupaya mengkaji pondasi ideologis Islam Liberal dan memperjelas sejauhmana ancamannya terhadap paham Ahl Sunah Waljamaah. Meskipun kehadiran Islam Liberal membawa hal baru, tetapi sesungguhnya bukan sama sekali baru. Penulis mengemukakan bahwa agenda-agenda kelompok Islam Liberal merupakan perluasan Imperialisme Barat atas Dunia Islam yang sudah berlangsung sekitar dua sampai tiga abad terakhir. Hanya saja, bentuknya memang tidak lagi terang-terangan, tetapi mengatasnamakan Islam. Jadi istilah "Islam Liberal" bukanlah suatu kebetulan, tetapi sebuah istilah yang dipilih dengan sengaja untuk mengurangi kecurigaan umat Islam dan sekaligus untuk menobatkan diri bahwa "Islam Liberal" adalah bagian dari Islam, seperti halnya jenis-jenis pemahaman Islam lainnya. Penulis menyimpulkan bahwa Islam liberal adalah peradaban Barat yang diartikulasikan dengan bahasa dan idiom-idiom keislaman. Islam hanyalah kulit atau kemasan, tetapi esensinya adalah ideologi dan peradaban Barat.
\end{abstract}

\begin{abstract}
Liberal Islam and its Threat against the Thought of Ahl Sunah Waljamaah. This paper attempts to tries to prove the declaration and tries to clarify the conflicts and threats to understand Ahl Sunnah waljamaah. Although the presence of Liberal Islam seems to have brought with it new thing, but it is by no means new phenomenon. The agendas of Liberal Islam groups are extensions of the western imperialism against the Islamic world during the last two or three centuries. However the form was no longer exposed, but it takes the name of Islam for granted. So, the term "Liberal Islam" is not a cooincidence, but a term chosen deliberatly to reduce the suspicion of moslems and also to enthrone itself that "Liberal Islam" is part of Islam, just as the types of other Islamic understanding. The author concludes that Liberal Islam is western civilization articulated with language and Islamic idioms. Islam is only the cover or packaging, but the essence is western ideology and civilization.
\end{abstract}

Kata Kunci: Islam Liberal, ancaman, Ahl Sunah Waljamaah 


\section{Pendahuluan}

Kata Islam berasal dari bahasa Arab, yang berarti selamat, sejahtera, tunduk dan patuh. Beberapa arti Islam ini bisa direkonsiliasikan, untuk dapat selamat dan sejahtera seseorang harus tunduk dan patuh terhadap semua aturan Allah SWT. Sebenarnya, alam semesta juga 'Islam' terhadap Allah. ${ }^{1}$ Kemudian, semua agama yang diturunkan oleh Allah SWT. kepada para nabi dan para rasul-Nya adalah Islam. Berikutnya, kata Islam itu dijadikan Allah untuk nama agama yang dibawa oleh nabi terakhir, yakni Nabi Muhammad SAW. Ini merupakan sesuatu yang sudah disengaja Allah SWT.

Kehadiran Islam sebagai agama wahyu yang terakhir dimaksudkan untuk meluruskan garis lurus agama-agama sebelumnya. Dalam artian, Islam tidak hanya membenarkan agama lain, juga kebenaran yang ada dan sekaligus mengemukakan pembenaran terhadap penyimpangan-penyimpangan yang terjadi di dalam agama-agama lain, kemudian memberikan penjelasan tentang kebenaran itu. Inilah keistimewaan Islam, ia terbuka terhadap unsur luar selama tidak bertentangan dengan prinsip dasar atau prinsip pokok dari ajaran-ajarannya.

Islam adalah agama rậmat lil al-'âlamîn (agama kasih sayang) yang amat sempurna. Ia cocok untuk segala tempat dan etnis (shaliḩ li kulli zamân wa makân). Islam adalah agama wahyu tahap terakhir dari proses evolusi agama sejak dari Nabi Adam as. Agama diturunkan Allah sesuai dengan tingkat kecerdasan manusia yang menerimanya. Agama yang diberikan kepada Nabi Adam as. adalah agama tingkat kecerdasan agama tingkat bayi. Begitulah seterusnya kepada nabi-nabi lain, tingkat kecerdasan anak-anak, remaja dan seterusnya. Karena itu, agama yang diturunkan kepada Nabi Muhammad SAW. yang disebut Islam adalah agama tingkat kecerdasan manusia yang sudah dewasa. Dengan demikian, bagaimanapun bentuk masalah baru yang muncul, sudah ada solusinya dalam al-Qur'an.

Perlu dikemukakan bahwa ayat-ayat al-Quran terdiri atas muhkkamât dan mutasyâbihât. ${ }^{2}$ Ayat muhkamât yaitu ayat-ayat yang artinya pasti sebagaimana yang diberikan terkesan tidak dapat ditafsirkan lagi. Sedangkan ayat mutasyâbihât, yaitu ayat-ayat yang artinya tidak pasti dan masih ada peluang untuk ditafsirkan.

Dalam Al-Quran paling banyak ayat-ayat yang berbentuk mutasyâbihât daripada ayat muhkkamât. Pada ayat mutasyâbihât inilah terjadi proses perkembangan ajaran Islam dalam berbagai aspek. Hal ini mengindikasikan adanya upaya penafsiran manusia dalam menyelesaikan persoalan kontemporer yang tidak ada dalilnya secara tegas di dalam alQuran maupun Sunnah, dengan catatan tidak keluar dari prinsip Islam. Penafsiran ini dilakukan guna menuai titik temu antara hakikat Islam dengan semangat zaman yang selalu mengalami perubahan.

${ }^{1}$ Q.S. Fushshilat/41: 11.

2Q.S. Âli 'Imrân/3: 7. 
Sejauh ini, telah terjadi perkembangan pemikiran Islam dalam beberapa bentuk. Islam Fundamentalis, misalnya, memahami Islam hanya sebatas lambang bukan substansi. Paham ini akan melahirkan sikap radikal dan emosional. Sedangkan bentuk lain adalah Islam Liberal, yang memahami Islam dengan mengandalkan sepenuhnya akal semata. Padahal akal manusia itu sangat terbatas, sehingga tidak heran jika paham ini mendobrak prinsip pokok Islam. Berkaca dengan dua kutub yang berseberangan ini, tampillah aliran Islam al-Wasâthiyyah atau yang lebih akrab dengan nama Ahl Sunnah Waljamaah. Paham ini berada di tengah antara kedua aliran di atas, dengan mengusung kebebasan berpikir manusia dalam menelaah nash al-Qur'an maupun hadis secara konstektual dengan syarat tidak keluar dari pokok Islam atau ayat-ayat muhkamât.

\section{Islam Liberal}

Islam berkembang sesuai dengan zamannya. Ia berjalan sesuai dengan lajunya sejarah kaum Muslim. Perjalanan pemikiran Islam ini juga dipengaruhi oleh naik turunnya kekuasaan pada abad ke-15, yaitu terjadi kemerosotan pemikiran Islam serta ditandai oleh kejumudan berpikir sehingga kekuasaan para penjajah menjadi kuat dihampir semua negara Islam yang terjajah, apalagi para penjajah ini juga membawa konsepsi pemikiran yang sengaja dikembangkan untuk menyingkirkan atau paling tidak mendistorsi pemikiran Islam. Dari itu, terjadi penurunan pemikiran di antara umat Islam sendiri.

Kelompok Islam Liberal ${ }^{3}$ adalah sebuah istilah yang diadopsi dari kategorisasi pengamat dan penulis asing, Leonard Binder dan Charles Kurzman. ${ }^{4}$ Binder mengemukakan pandangan-pandangannya yang ingin mendapatkan penghargaan tentang berpikir yang liberal. Sementara itu, Kurzman memberikan pendapat bahwa sejatinya Islam itu sebuah agama yang mendorong adanya liberalism yaitu memberikan keluasan pada umatnya untuk mempergunakan akal sebagai perangkat yang akan berguna dalam memahami agama.

${ }^{3}$ Sebagai sebuah pemikiran, Islam Liberal sesungguhnya bukanlah fenomena baru, ia telah ada sejak gagasan kebangkitan dan pembaruan pemikiran Islam muncul pada awal abad ke-19. Penamaan "Islam Liberal" yang baru beberapa tahun belakangan popular, hanyalah merupakan reinkarnasi dari istilah yang pernah digunakan baik secara eksplisit maupun implisit oleh penulis-penulis sebelum Kurzman, seperti Albert Hourani dan Asaf Ali Ashgar Fyzee. Penggunaan kembali istilah "Islam Lieberal" sesungguhnya merupakan upaya untuk mengembalikan semangat kebangkitan (nahdhah) pemikiran Islam yang sejak satu abad silam telah dibajak oleh Konservatisme dan Fundamentalisme agama. Bagaimanapun, istilah "Islam Liberal" hanyalah tatakata (nomenklatur) sekadar untuk memudahkan seseorang merujuk sebuah gagasan atau gerakan yang memiliki cita-cita untuk membebaskan umat Islam dari keterbelakangan dan kejumudan satu hal sesungguhnya merupakan raison d 'etre kebangkitan Islam sejak dua ratus tahun silam. Lihat A. A. A Fyzee, A Modern Approach to Islam (London: Asia Pub. House, 1963).

${ }^{4}$ Charlez Kurszman, professor sosiologi agama di University North Carolina, memperkenalkan istilah atau gerakan baru di Dunia Islam ini dalam bukunya, Islamic Liberalism telah diterjemahkan dan diberi judul Wacana Islam Liberal: Pemikiran Islam Terkini (Contemporary) tentang Isu-isu Global. Sebenarnya, Kurzman bukan orang pertama, karena sebelumnya telah muncul Leonard 
Di samping itu, ada juga beberapa tokoh dunia menilai Islam dengan nada miring, seperti halnya ungkapan-ungkapan para orientalis. Voltaire (1745) misalnya, dalam bukunya Mahomet of Fanaticism, menilai bahwa Islam identik dengan kefanatikan. Dalam terminologi politik, "kekuasaan Islam berarti dispotisme (kesewenang-wenangan)," kata Montesquie. Kemudian dukung juga oleh Francis Bacon (1622) yang mengidentikkan kekuasan Islam dengan Monarki Absolut. Sedangkan di bidang militer, Islam identik dengan teror seperti diungkap oleh Eugene Delacroix (1824). Bahkan sastrawan Ernest Renon (1862) berpendapat bahwa tradisi Islam identik dengan keterbelakangan dan primitive. Dari pandangan Kurzman dan para tokoh orientalis di atas, bisa dikategorikan bahwa mereka "mengiring" Islam seperti liberal Barat. Padahal terdapat perbedaan yang mendasar antara keduanya, karena Islam itu masih berpijak kepada al-Qur'an dan Hadis, sedangkan Islam Liberal telah melanggar prinsip muhkamât.

Meskipun kehadiran kelompok Islam Liberal, oleh sebagian orang, membawa hal-hal baru, namun sesungguhnya ia bukanlah sama sekali baru. Islam Liberal adalah peradaban Barat yang diartikulasikan dengan bahasa dan idiom-idiom keislaman. Islam hanyalah sebagai kemasan, sementara substansinya adalah ideologi Barat, bukan yang lain. Dalam misinya banyak imitasi sempurna terhadap ideologi Kapitalisme. Tentu, dalam hal ini, ada kreativitas dan modifikasi, khususnya pencarian ayat atau hadis, atau preseden sejarah yang kemudian diinterpretasikan secara paksa agar cocok dengan kapitalisme. ${ }^{5}$

Untuk membuktikan deklarasi tersebut, berikut ini akan dijelaskan dua dasar argumentasinya, yaitu hakikat Imperialisme itu sendiri dan kerangka Ideologi Barat (Kapitalisme). ${ }^{6}$

\section{Imperialisme}

Imperialisme (al-isti'mar) itu sendiri, menurut Taqi' al-Dîn al-Nabhânî dalam

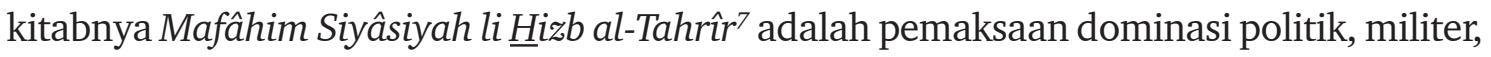
budaya, dan ekonomi atas negeri-negeri yang dikalahkan untuk kemudian dieksploitasi. Dua kata kunci imperialisme yang patut dicatat: pemaksaan dominasi dan eksploitasi.

Binder yang coba menyebarkan paham tersebut dalam bukunya, Islamic Liberalism: A Critique of Development Ideologies.

${ }^{5}$ Dzulmanni (ed.), Islam Liberal dan Fundamental: Sebuah Pertarungan Wacana, Cet. 6, (Yogyakarta: eLSAQ Press, 2007), h. 236.

${ }^{6}$ Pemahaman hakikat Imperialisme, akan menjadi landasan untuk memilah apakah suatu agenda termasuk aksi Imperialisme atau bukan. Sedangkan kerangka ideologi Kapitalisme akan menjadi dasar untuk menilai apakah sebuah pemikiran termasuk dalam ideologi Kapitalisme atau bukan, atau untuk mengevaluasi sebuah metode berpikir, apakah ia metode berpikir kapitalistik atau bukan. h. 13.

${ }^{7}$ Taqi al-Dîn al-Nabhânî, Mafâhim Siyâsiyah li Hizb al-Tahrir (t.t.p. Hizb al-Tahrir, 1969), 
Jika sebuah negara melakukan aksi Imperialisme atas negara lain. Artinya, negara penjajah itu akan memaksakan kehendaknya kepada negara lain, sehingga negara yang dijajah itu mau tidak mau harus mengikuti negara penjajah dalam hal haluan politiknya, program ekonomi rancangannya, budaya dan cara berpikirnya, serta pembatasan dan penggunaan sarana militernya. Semua ini adalah demi keuntungan negara penjajah sendiri. Jika negara yang dijajah menolak atau melawan, ia akan mendapat sanksi dan hukuman dari sang penjajah. Inilah hakikat Imperialisme.

Imperialisme ini, menurut al-Nabhânî ${ }^{8}$ adalah metode (tharîqah) baku untuk menyebarluaskan ideologi Kapitalisme yang berpangkal pada Sekularisme (fashl al-dîn 'an al-hayâh). Tidak mungkin ada penyebarluasan Kapitalisme, kecuali melalui jalan Imperialisme. Dengan kata lain, manakala negara penganut Kapitalisme ingin menancapkan cengkeramannya pada negara lain, ia akan melakukan aksi-aksi Imperialisme dalam segala bentuknya, baik dalam aspek politik, ekonomi, budaya, atau militer. Berhasil tidaknya aksi imperialisme ini, diukur dari sejauh mana ideologi Kapitalisme tertanam dalam jiwa penduduk negeri jajahan dan sejauh mana negara penjajah mendapat manfaat dari aksi penjajahannya itu. Jika penduduk negeri jajahan sudah mengimani Kapitalisme, atau dari negeri itu dapat diambil berbagai keuntungan bagi kepentingan imperialis, berarti aksi Imperialisme telah sukses.

\section{Kerangka Ideologi Kapitalisme}

Kapitalisme pada dasarnya adalah nama sistem ekonomi yang diterapkan di Barat. Milton H. Friedman dalam Contemporary Macro Economics, dikutip Muhammad Shiddiq alJawi, ${ }^{9}$ mengatakan bahwa Kapitalisme adalah sistem organisasi ekonomi yang bercirikan kepemilikan individu pada sarana produksi dan distribusi, serta pemanfaatan sarana produksi dan distribusi itu dalam mekanisme pasar yang kompetitif. Karena fenomena ekonomi itu sangat menonjol dalam peradaban Barat, maka menurut Taqi' al-Dîn al-Nabhânî, Kapitalisme kemudian digunakan juga untuk menamai ideologi yang ada di negara-negara Barat, sebagai sistem sosial yang menyeluruh. ${ }^{10}$

Sebagai sebuah ideologi (Arab: mabdâ'), kapitalisme mempunyai 'aqîdah (ide dasar) dan ide-ide cabang yang dibangun di atas akidah tersebut. Akidah di sini dipahami sebagai pemikiran menyeluruh (fikrah kulliyah) tentang alam semesta, manusia dan kehidupan, serta tentang apa yang ada sebelum dan sesudah kehidupan dunia. Akidah Kapitalisme adalah pemisahan agama dari kehidupan (Sekularisme), sebuah ide yang muncul di Eropa sebagai jalan tengah antara dua ekstrim, yaitu keharusan dominasi agama

${ }^{8}$ Ibid.

${ }^{9}$ Muhammad Shiddiq al-Jawi, "Catatan Kritis Untuk Islam Liberal," (Makalah tidak diterbitkan), h. 2-3.

${ }^{10}$ Taqi' al-Dîn al-Nabhânî, Nizhâm al-Islâm, Cet. 6 (t.t.p.: Hizb al-Tahrir, 2001), h. 26. 
(Katolik) dalam segala aspek kehidupan, dan penolakan total eksistensi agama (Katolik). Akhirnya, agama tetap diakui eksistensinya, hanya saja perannya dibatasi pada aspek ritual, tidak mengatur urusan kehidupan seperti politik, ekonomi dan sosial. ${ }^{11}$

Di atas akidah (ide dasar) Sekularisme ini, dibangunlah berbagai ide cabang dalam ideologi Kapitalisme, seperti demokrasi dan kebebasan. Ketika agama sudah dipisahkan dari kehidupan, berarti agama dianggap tidak punya otoritas lagi untuk mengatur kehidupan. Jika demikian, maka manusia itu sendirilah yang mengatur hidupnya, bukan agama. Dari sinilah lahir demokrasi, yang berpangkal pada ide menjadikan rakyat sebagai sumber kekuasaan-kekuasaan (legislatif, eksekutif dan yudikatif) sekaligus pemilik kedaulatan (pembuat hukum). ${ }^{12}$

Demokrasi ini selanjutnya membutuhkan prasyarat kebebasan. Sebab, tanpa kebebasan, rakyat tidak dapat mengekspresikan kehendaknya dengan sempurna, baik ketika rakyat berfungsi sebagai sumber kekuasaan, maupun sebagai pemilik kedaulatan. Kebebasan ini dapat terwujud dalam kebebasan beragama (hurriyah al-tamalluk), kebebasan berpendapat (hurriyah al-ra'y) dan kebebasan berperilaku (al-hurriyah al-syakhshiyyah). ${ }^{13}$

Dalam kontek Indonesia, Islam Liberal sebenarnya menawarkan wacana baru tentang Islam di Indonesia yang dikemas secara modern, professional dan berkesinambungan dengan masa lalu. Tetapi, sayangnya langkah yang mereka lakukan tidak benar sama sekali. Di Indonesia, gagasan Islam Liberal diteliti oleh Greg Barton ${ }^{14}$ yang ditulis dalam disertasi doktornya di Monash University, Melbourne, Australia. Penelitian ditekankan tahun 1960 sampai 1990. Gerakan dan pemikiran ini telah berpengaruh pada tataran keagamaan, sosial dan politik. Gerakan ini secara luas tumbuh di lingkungan para intelektual yang memiliki latar belakang modern yang dikombinasikan dengan pendidikan Islam Klasik. Kemunculannya di Indonesia menurutnya sebagai pendorong bagi terbitnya kebangkitan baru satu generasi Muslim terutama kelas menengah kota sehingga mampu berperan secara lebih liberal dan progresif untuk sebuah Indonesia baru.

\section{Tema-Tema Sentral Pemikiran Islam Liberal}

Menarik sekali discourse yang dikembangkan oleh komunitas Islam Liberal, seperti membuka pintu ijtihad selebar-lebarnya, kontekstual, kesetaraan gender pluralisme agama dan sekularisasi. Ada beberapa pokok pemikiran Islam Liberal. ${ }^{15}$

${ }^{11}$ Ibid., h. 28.

${ }^{12}$ Ibid., h. 27.

${ }^{13}$ Abd. al-Qadim Zallum, Demokrasi Sistem Kufur, terj. Muhammad Shiddiq al-Jawi (Bogor, Pustaka Thariq al-Izzah, 1994), h. 17.

${ }^{14}$ Greg Barton, Gagasan Islam Liberal di Indonesia, terj. Nanang Tahqiq (Jakarta: Paramadina, 1998).

${ }^{15}$ Penjelasan secara mendalam lihat Charles Kurzman, Wacana Islam Liberal: Pemikiran 
Pertama. Islam Liberal percaya bahwa ijtihad atau penalaran rasional atas teks-teks keislaman adalah prinsip utama yang memungkinkan Islam terus bisa bertahan dalam segala cuaca. Penutupan pintu ijtihad, baik secara terbatas atau secara keseluruhan adalah ancaman atas Islam itu sendiri, sebab dengan pemikiran Islam akan mengalami pembusukan. Islam Liberal percaya bahwa ijtihad bisa diselenggarakan dalam semua segi, tanpa dibatasi nas muhkkamât.

Kedua. Islam Liberal mendasarkan diri pada gagasan tentang kebenaran yang relatif, sebab sebuah penafsiran adalah kegiatan manusiawi yang terkungkung oleh konteks tertentu: terbuka, sebab setiap bentuk penafsiran mengandung kemungkinan salah, selain kemungkinan benar dan plural, sebab penafsiran keagamaan, dalam satu dan lain cara adalah cerminan dari kebutuhan seorang penafsir di suatu masa dan ruang yang terus berubah-ubah.

Ketiga. Seain itu, Islam liberal meyakini bahwa urusan beragama dan tidak beragama adalah hak perorangan yang harus dihargai dan dilindungi. Islam Liberal tidak membenarkan penganiayaan atas dasar suatu pendapat atau kepercayaan.

Keempat. Islam Liberal yakin bahwa kekuasaan keagamaan dan politik harus dipisahkan. Islam Liberal menentang negara agama (teokrasi). Islam Liberal yakin bahwa bentuk negara yang sehat bagi kehidupan agama dan politik adalah negara yang memisahkan kedua wewenang tersebut. Agama adalah sumber inspirasi yang dapat mempengaruhi kebijakan publik, tetapi agama tidak punya hak suci untuk menentukan segala bentuk kebijakan publik. Agama berada di ruang privat dan urusan publik harus diselenggarakan melalui proses konsensus. ${ }^{16}$

\section{Ahl Sunah Waljamaah}

Munculnya Ahl Sunah Waljamaah sebagai sebuah sistem atau paham tidak lepas dari kondisi sosio politik pada masa awal Islam yang berkisar pada paruh awal abad ke3 Hijriyah, di mana kekuasaan politik Islam baru mengalami masa transisi dari kekuasaan Dinasti Umayyah ke Dinasti Abbasiyah. Pada masa itu sangat marak tradisi intelektual, baik dalam bentuk perwujudan karya lokal ataupun pemindahan karya luar untuk proses transpormasi internal. Perhatian Dinasti Abbasiyah terhadap pengembangan ilmu pengetahuan begitu tampak, dan seakan menjadi prioritas proyek pembangunan rezim

Islam Terkini tentang Isu-Isu Global, terj. Bahrul Ulum (Jakarta: Paramadina, 2001); Zuly Qadir dan Luthfi Assyaukanie, Wajah Liberal Islam di Indonesia (Jakarta: Teater Utan Kayu, 2002).

${ }^{16}$ Khalif Muammar, Atas Nama Kebenaran: Telaah Kritis Terhadap Wacana Islam Liberal (Selangor: Akademi Pengajian Tamadun, Universiti Kebangsaan Malaysia, 2001), h. 32. Lihat Juga Ulil Abshar Abdalla et. al. Islam Liberal dan Fundamental: Sebuah Pertarungan Wacana, Cet. 6 (Yogyakarta: eLSAQ Press, 2007), h. 8. 
kekuasaannya. ${ }^{17}$ Selain itu, mulai lahir beragam pemikiran umat Islam dalam merespons berbagai persoalan yang baru muncul ketika itu. Tepatnya di bawah kepiawaian intelektual Abû al-Hasan al-Asy'ârî (w. 324 H.) dan Abû al-Manshûr al-Matûrîdî (w. 333 H.). ${ }^{18}$ Ahl Sunah Waljamaah sebagai paham dan teologi independen mulai diperkenalkan.

Pada era kenabian, umat Islam masih bersatu, dalam artian tidak ada golongan A dan tidak ada golongan B. Tidak ada pengikut akidah A dan tidak ada pengikut akidah B, semua berada di bawah pimpinan dan komando Rasulullah SAW. Bila terjadi masalah atau perbedaan pendapat antara para sahabat, mereka langsung datsng kepada Rasulullah SAW. Itulah yang menjadi para sahabat saat itu tidak sampai terpecah belah, baik dalam masalah akidah, maupun dalam urusan duniawi. Kemudian setelah Rasulallah SAW. wafat benih-benih perpecahan mulai tampak dan puncaknya terjadi saat Imam 'Alî ra. menjadi Khalifah. Namun perpecahan tersebut hanya bersifat politik, sedangkan akidah mereka tetap satu, meskipun saat itu benih-benih penyimpangan dalam akidah sudah mulai ditebarkan oleh Ibn Saba', seorang yang dalam sejarah Islam dikenal sebagai pencetus paham Syi ah (Rawâfidh). ${ }^{19}$

Setelah para sahabat wafat, benih-benih perpecahan dalam akidah tersebut mulai membesar, sehingga timbullah paham-paham yang bermacam-macam yang dapat dikatakan "menyempal" dari ajaran Rasulullah. Saat itu umat Islam terpecah dalam dua bagian, satu bagian dikenal sebagai golongan-golongan ahli bidah, atau kelompok-kelompok sempalan dalam Islam. Sedang bagian yang satu lagi adalah golongan terbesar, yaitu golongan orangorang yang tetap berpegang teguh kepada segala hal yang dikerjakan dan diyakini oleh Rasulullah SAW. bersama sahabat-sahabatnya. Golongan yang terakhir inilah yang dikemudian menamakan golongan dan akidahnya Ahl Sunah Waljamaah. Jadi, golongan Ahl Sunah Waljamaah adalah golongan yang mengikuti sunnah-sunnah Nabi dan Jam'at al-Shahabah. ${ }^{20}$ Dengan demikian, akidah Ahl Sunah Waljamaah adalah akidah Islam yang dibawa oleh Rasulullah SAW. dan golongan Ahl Sunah Waljamaah adalah umat Islam.

Mengetahui siapa Ahl Sunnah Waljamaah adalah perkara yang sangat penting dan salah satu bekal yang harus ada pada setiap Muslim yang menghendaki kebenaran. Sehingganya dalam perjalanannya di muka bumi, ia berada di atas pijakan yang benar dan jalan yang lurus dalam menyembah Allah SWT. dengan tuntutan syariat yang dibawa oleh Rasulullah SAW. 14 abad yang lalu.

Pengenalan akan siapa sebenarnya Ahl Sunah Waljamaah telah ditekankan

${ }^{17}$ Harun Nasution, Teologi Islam: Aliran-Aliran Sejarah Analisa Perbandingan (Jakarta: UI Press, 2002), h. 62.

${ }^{18}$ Ibid.

${ }^{19}$ Ibid., h. 64.

${ }^{20} I b i d .$, h. 65-66. Statemen tersebut sesuai dengan hadis Rasullah SAW. yang menjelaskan bahwa "golongan yang selamat dan akan masuk surga (al-firqah al-Najiyah). Adalah golongan yang mengikuti apa-apa yang aku (Rasulullah SAW.) kerjakan bersama sahabat-sahabatku". 
Rasulullah kepada para sahabatnya ketika ia berkata kepada mereka bahwa telah terpecah orang-orang Yahudi menjadi tujuh puluh satu aliran (golongan) dan telah terpecah orang-orang Nasrani menjadi tujuh puluh dua aliran dan sesungguhnya umatku akan terpecah menjadi tujuh puluh tiga aliran semuanya dalam neraka kecuali satu dan ia adalah al-Jamấah. ${ }^{21}$

Munculnya perselisihan tersebut bukan berarti Allah tidak mampu menjadikan satu ragam pendapat saja di muka bumi ini. ${ }^{22}$ Itu suatu hal yang sangat mustahil bagi Allah karena Dia satu-satunya yang mendesain alam ini sebaik mungkin. Maka dari itu sebagai manusia yang berakal, hikmah yang dapat diambil adalah Allah memberikan pilihan atau kebebasan yang seluasnya, tentu ada resiko atau batas-batasnya kepada hambaNya, supaya kelihatan siapa yang mencari kebenaran dan siapa yang mementingkan hawa nafsu dan sikap fanatisme.

Adapun penamaan Ahl al-Sunnah Waljamaah ini akan diuraikan dari beberapa sisi. Pertama, definisi Sunnah (bahasa) yaitu berarti jalan, baik maupun jelek dan lurus maupun sesat. ${ }^{23}$ Kedua, Sunnah (istilah), yaitu mempunyai makna khusus dan makna umum. Adapun makna Sunnah secara khusus yaitu 1) Para ahli hadis mendefinisikan sunnah sebagai apa-apa yang disandarkan kepada Nabi Muhammad SAW. baik itu perkataan, perbuatan, taqrîr, maupun sifat lahir dan akhlak. 2) Para ahli usul fikih mendefinisikan sunnah sebagai apa-apa yang datang dari Nabi Muhammad SAW. selain dari al-Qur'an, sehingga meliputi perkataan beliau, pekerjaan, taqrîr, surat, isyarat, kehendak beliau melakukan sesuatu atau apa-apa yang beliau tinggalkan. 3) Para ahli fikih memberikan definisi sunnah sebagai hukum yang datang dari Nabi Muhammad SAW. di bawah hukum wajib. Sedangkan makna sunnah secara umum adalah Islam itu sendiri secara sempurna yang meliputi akidah, hukum, ibadah dan seluruh bagian syariat. Ketiga, definisi al-Jamấah, bermakna menyatukan sesuatu yang terpecah, maka Jamâ'ah adalah lawan kata dari perpecahan. Adapun dalam pengertian sederhananya, al-Jamâ'ah ialah orang-orang yang telah sepakat berpegang dengan kebenaran yang pasti sebagaimana tertera dalam al-Qur'an dan al-hadis dan mereka itu ialah para sahabat dan tabi'in. Jadi, makna Ahl Sunah Waljamaah adalah para sahabat, tabi'in dan orang-orang yang mengikuti mereka dengan baik dari para ulama ahli ijtihad dan ahli hadis yang berjalan di atas al-Qur'an dan Sunnah.

Penekanan pada sunnah bukan berarti penafian terhadap al-Qur'an yang disepakati sebagai sumber yang utama dalam Islam. Kandungan Al-Qur'an begitu umum sehingga

\footnotetext{
${ }^{21}$ Hadis sahih yang disahihkan oleh oleh Syaikh al-Albânî dalam Dzilâlil Jannah dan Syaikh Muqbil dalam al-Shahîh $\underline{h}$ al-Musnad Mimmâ Laisa fî al-Shahn̂hhain.

${ }^{22}$ Q. S. Hûd/11: 118-119.

${ }^{23}$ Harun Nasution, Teologi Islam, h. 65.
} 
berpeluang untuk ditafsirkan dalam untuk rangka menjawab persoalan kekinian, sepanjang tidak melanggar prinsip-prinsip Islam. ${ }^{24}$

Di Indonesia, kata-kata Ahl Sunah Waljamaah (ASWAJA) sudah cukup lama munculnya. Lebih dari 70 tahun yang lalu, Nahdlatul Ulama (NU) mendeklarasikan dirinya sebagai penganut ASWAJA, ${ }^{25}$ sebagaimana Muhammadiyah dan kaum Muslim di luar kedua ormas ini.

Ada beberapa pokok pemikiran ASWAJA. Pertama. Ahl Sunah Waljamaah mempersatukan agama melalui ilmu dan amalan lahir dan batin, dengan selalu berpegang kepada kemurnian Islam yang dibawa Nabi Muhammad SAW dan dipelihara oleh para sahabatnya. Iktikad golongan yang selamat adalah gambaran yang dipredikatkan oleh Nabi Muhammad SAW dengan keselamatan. ${ }^{26}$ Kedua. Ahl Sunah Waljamaah adalah golongan tengah dan lurus di antara berbagai kelompok umat, yaitu antara golongan yang melebihkan dan mengurangi ketentuan agama. Ketiga. Ahl Sunah Waljamaah berpegang teguh kepada alQur'an, Sunnah dan Ijma'. Golongan ini taat mengikuti petunjuk dan larangan yang datang dari Allah. Keempat. Ahl Sunah Waljamaah adalah penerus sejarah bagi penganut agama Islam. Golongan ini adalah asal-muasal dalam umat Muhammad. Mereka juga merupakan penerus tabiat alami dan benar bagi pemeluk agama ini, sebagaimana halnya millah Nabi Muhammad SAW. menjadi penerus alami dan benar bagi agama-agama para nabi pendahulunya. Kelima. Ahl Sunah Waljamaah adalah ahli syariat yang mengikuti sunnah rasul yang meliputi semua aspek ajaran Islam baik akidah, perbuatan-perbuatan, tujuan-tujuan esensi, ibadah-ibadah maupun siyâsat syar'iyyah. Sunnah, sebagaimana halnya syari'at, adalah segala sesuatu yang disunahkan dan disyariatkan Rasul dalam akidah dan amalan, yang keduanya mengandung makna yang sama. Keenam. Ahl Sunah Waljamaah hanya mengambil sumber hukum yang kuat ketetapannya dari Rasul dan Salafal-Shalih. . Hal itu dapat diketahui berdasarkan pengetahuan tentang hadis-hadis Nabi yang telah menjadi ketetapan, baik dalam perkataan, perbuatan dan taqrîr-nya. Ketujuh. Ahl Sunah Waljamaah adalah orang-orang yang mencintai hadis Nabi Muhammad SAW. dan taat mengikutinya. Ahli Sunnah dan Ahli Hadis bukanlah mereka sekedar sibuk berperan dalam urusan ilmu hadis, namun juga mereka yang mencintai dan mencurahkan perhatian kepadanya. Kedelapan. Ahl Sunah Waljamaah memiliki tingkatan yang beragam dalam mengetahui Sunnah, mengamalkannya serta bersabar terhadapnya. Sunnah adalah segala sesuatu yang diterima oleh para sahabat dari Rasulullah SAW., kemudian

${ }^{24}$ Sirajuddin Zar, "Islam dalam Kepemimpinan Indonesia," dalam al-Turas, Oktober 1995. Januari 1996, h. 38-41.

${ }^{25}$ Fu'ad Jabali, "Telaah Kritis Konsep Aswaja," dalam Luthfi Assyaukanie, Wajah Liberal Islam di Indonesia (Jakarta: Teater Utan Kayu, 2002), h. 64.

${ }^{26}$ Ungkapan tersebut sesuai dengan penjelasan Rasul bahwa "umatku akan terpecahbelah menjadi 73 golongan; yang 72 golongan masuk neraka dan yang satu masuk surga. Golongan ini adalah yang mengikuti jalan hidup seperti yang aku tempuh hari ini dan jalan para sahabat". 
diteruskan kepada para tabi'in, tabi'in dan seterusnya sampai hari kiamat. Sebagian imam juga lebih mengetahui dan lebih mampu bersabar terhadapnya dari sebagian imam yang lain. Kesembilan. Di tubuh Ahl Sunah Waljamaah terdapat perbedaan ijtihad dalam hal-hal cabang (furû́), sesuai dengan tingkat pengetahuan mereka terhadap Sunnah. Kesepuluh. Ahl Sunah Waljamaah senantisa berupaya agar perbedaan ijtihad mereka mengarah kepada satu pendapat dan menjaga kerukunan. Sekalipun terdapat perbedaan dalam ijtihad, mereka saling menjaga dan mengontrol perilakunya untuk saling menghormati. Mereka memiliki adab yang sopan dalam berbeda pendapat (ikhtilâf). Semua itu mereka lakukan karena menjaga kerangka besar dan prinsipil, yaitu kerangka golongan Ahl Sunnah Waljamaah. Tetapi, terhadap orang atau golongan yang berbeda pendapat dalam hal pokok dan mendasar, mereka tidak menerimanya dan melepaskan diri darinya. Mereka dengan keras mengecamnya serta membeberkan kesalahan-kesalahan dan penyelewengannya agar umat mengetahuinya. Kesebelas. Ahl Sunah Waljamaah adalah manusia biasa, di antara mereka ada yang baik (berlaku benar) dan ada yang maksiat. Namun, pada umumnya mereka berprilaku baik, sebagaimana halnya golongan lain yang banyak melakukan keburukan. Keduabelas. Ahl Sunah Waljamaah adalah mayoritas umat Muhammad SAW. yang berpegang teguh kepada al-Qur'an dan sunnah Rasul, mencintai para sahabat dan mengambil hadis Nabi Muhammad SAW. dari mereka, baik dalam hal ilmu, amalan ataupun fikih dan perilaku.

\section{Menyoal Islam Liberal}

Agenda-agenda dan ide-ide Kelompok Islam Liberal dapat dipahami dalam kerangka kepanjangan Imperialisme Barat atas Dunia Islam. Selain itu, ide-ide Kelompok Islam Liberal itu sendiri, dapat dipahami sebagai ide-ide pokok dalam ideologi Kapitalisme, yang kemudian dicari-cari pembenarannya dari khazanah Islam. ${ }^{27}$

Mereka yang mencermati dan mengkritisi agenda dan pemikiran kelompok Islam Liberal, kiranya akan menemukan benang merah antara Imperialisme Barat dan agenda kelompok Islam Liberal. Adian Husaini dan Nuim Hidayat, dalam bukunya Islam Liberal: Sejarah, Konsepsi, Penyimpangan, dan Jawabannya, mengutip Luthfi Asy-Syaukanie, bahwa setidaknya ada empat agenda utama Islam Liberal, yaitu agenda politik, agenda toleransi agama, agenda emansipasi wanita, dan agenda kebebasan berekspresi. ${ }^{28}$ Dalam agenda politik, misalnya, kaum Muslim “diarahkan” oleh kelompok Islam Liberal untuk mempercayai Sekularisme, dan menolak sistem pemerintahan Islam (Khilâfah). Perdebatan sistem

\footnotetext{
${ }^{27}$ Paparan dua pemikiran tentang Imperialisme dan kerangka ideologi Kapitalisme dapat dijadikan sebagai pisau analisis untuk membedah Kelompok Islam Liberal, untuk menjawab pertanyaan bahwa benarkah agenda-agenda Kelompok Islam Liberal adalah kepanjangan Imperialisme Barat? Benarkah ide-ide Kelompok Islam Liberal adalah ideologi Kapitalisme berkedok Islam?

${ }^{28}$ Adian Husaini dan Nuim Hidayat, Islam Liberal Sejarah: Konsepsi, Penyimpangan, dan Jawabannya (Jakarta: Gema Insani Press, 2002), h. 3.
} 
pemerintahan Islam, kata Luthfi, dianggap sudah selesai, karena, sudah ada para intelektual seperti 'Ali 'Abd al-Razîq, Ahmad Khalafallâh (Mesir), Mahmud Taleqani (Iran) dan Nurcholish Madjid (Indonesia) yang mengatakan bahwa persoalan tersebut adalah masalah ijtihad dan diserahkan sepenuhnya kepada kaum Muslim. ${ }^{29}$

Persoalan hubungan agama dan negara, memang boleh dikatakan sudah selesai di negara-negara Barat. Namun persoalan ini jelas belum selesai di Dunia Islam. ${ }^{30}$ Dari sini dapat dipahami, bahwa tugas kelompok Islam Liberal adalah membuat selesai persoalan yang belum selesai ini. Maka ada kesejajaran antara agenda kelompok Islam liberal dalam agenda politik ini dengan aksi Imperialisme Barat, yang selalu memaksakan Sekularisme di Dunia Islam dengan kekerasan dan darah.

Agenda-agenda lainnya di bidang toleransi (pluralisme agama), misalnya anggapan semua agama benar dan tidak boleh ada truth claim, agenda emansipasi wanita, seperti menyamaratakan secara absolut peran atau hak pria dan wanita tanpa kenal kecuali (dan tanpa ampun), dan agenda kebebasan berekspresi, seperti hak untuk tidak beragama (astagfirullah), tak jauh bedanya dengan agenda politik di atas. Semua ide-ide ini pada ujung-ujungnya, pada muaranya, kembali kepada ideologi dan kepentingan imperialis. Sulit sekali mencari akar pemikiran-pemikiran tersebut dari Islam itu sendiri secara murni, kecuali setelah melalui pemerkosaan teks-teks al-Qur'an dan hadis. Misalnya teologi Pluralisme yang menganggap semua agama benar, sebenarnya berasal dari hasil Konsili Vatikan II (1963-1965) yang merevisi prinsip extra ecclesium nulla salus (di luar Katolik tidak ada keselamatan) menjadi teologi inklusif-pluralis, yang menyatakan keselamatan dimungkinkan ada di luar katolik. ${ }^{31}$ Infiltrasi ide tersebut ke tubuh umat Islam dengan justifikasi ayatayat al-Quran ${ }^{32}$ Jelas sia-sia, karena kontradiktif dengan ayat-ayat yang menegaskan kebatilan agama selain Islam. ${ }^{33}$

Agenda-agenda kelompok Islam Liberal tersebut jika dibaca dari perspektif kritis, menurut Adian Husaini dan Nuim Hidayat, bertujuan untuk menghancurkan Akidah

${ }^{29} \mathrm{Ibid}$. Statemen di atas mengundang segudang pertanyaan. Pertanyaannya adalah, sejak kapan kaum Muslim menganggap persoalan ini "sudah selesai"? Apakah sejak 'Ali 'Abd al-Raziq menulis kitabnya al-Islâm wa Ushûl al- $\underline{H} u k m$ (1925) yang sesungguhnya adalah karya orientalis Inggris Thomas W. Arnold? Apakah sejak Khilafah di Turki dihancurkan pada tahun 1924 oleh gembong Imperialis, Inggris dengan menggunakan Mustahafa Kamal ? Apakah sejak negara-negara imperialis melalui penguasa-penguasa Dunia Islam yang kejam menumpas upaya mewujudkan kembali sistem pemerintahan Islam? Apakah nama-nama intelektual yang disebut Luthfi cukup representatif mewakili umat Islam seluruh dunia di sepanjang masa, ataukah mereka justru menyuarakan aspirasi penjajah? Pertanyaan-pertanyaan seperti ini perlu jawaban dengan pembuktian-pembuktian yang argumentatif.

${ }^{30}$ Robert Audi, Agama dan Nalar Sekuler dalam Masyarakat Liberal (Yogyakarta: UII Press, 2002), h. xvii-xviii.

${ }^{31}$ Husaini dan Hidayat, Islam Liberal, h. 110-111.

${ }^{32}$ Antara lain lihat Q. S. al-Baqarah/2: 62 dan Q.S. al-Mâ'idah/5: 69.

${ }^{33}$ Q.S. Âli 'Imrân/3: 19 dan Q. S. al-Taubah/9: 29. 
Islamiyah dan Syariah Islamiyah. ${ }^{34}$ Tentunya mudah dipahami, bahwa setelah akidah dan syariah hancur, maka sebagai penggantinya adalah akidah penjajah (sekularisme) dan syariah penjajah (hukum positif warisan penjajah). Di sinilah titik temu agenda kelompok Islam Liberal dengan proyek imperialisme Barat. Maka, tidak berlebihan kiranya jika dikatakan bahwa agenda kelompok Islam Liberal adalah kepanjangan Imperialisme global atas Dunia Islam yang dijalankan negara-negara Barat kapitalis, khususnya Amerika Serikat.

Ini dari segi kaitan agenda kelompok Islam Liberal dengan imperialisme. Adapun ide-ide kelompok Islam Liberal itu sendiri, maka berdasarkan kerangka ideologi kapitalisme yang telah disinggung secara singkat di atas, dapatlah kiranya dinyatakan bahwa ideide kelompok Islam Liberal sesungguhnya adalah ide-ide Kapitalisme. Luthfi Asy-Syaukanie dalam Wajah Liberal Islam di Indonesia telah berhasil menyajikan deskripsi dan peta ideide kelompok Islam Liberal. ${ }^{35}$ Jika dikritisi, kesimpulannya adalah di sana ada banyak imitasi (baca: taklid) sempurna terhadap ideologi Kapitalisme. Tentu ada kreativitas dan modifikasi. Khususnya pencarian ayat atau hadis atau preseden sejarah yang kemudian ditafsirkan secara paksa agar cocok dengan Kapitalisme.

Ide-ide Kapitalisme itu misalnya sekularisme, demokrasi dan kebebasan. Dukungan kepada sekularisme -pengalaman partikular barat-nampak misalnya dari penolakan terhadap bentuk sistem pemerintahan Islam, ${ }^{36}$ dan penolakan syariat Islam. ${ }^{37}$ Demokrasi pun begitu saja diterima tanpa nalar kritis dan dianggap kompetibel dengan nilai-nilai Islam seperti 'adl (keadilan), persamaan (musâwah) dan syurâ..$^{38}$ Kebebasan yang absolut tanpa mengenal batas, yang nampaknya sangat disakralkan kelompok Islam Liberal, didukung dalam banyak statemen dengan beraneka ungkapan seperti "tidak boleh ada pemaksaan jilbab," 39 "harus ada kebebasan tidak beragama,"40 dan "orang beragama tidak boleh dipaksa." 41

Kentalnya ide-ide pokok Kapitalisme dan berbagai derivatnya ini, masih ditambah dengan suatu metode berpikir yang kapitalistik pula, yaitu menjadikan ideologi Kapitalisme sebagai standar pemikiran. Ide-ide Kapitalisme diterima lebih dulu secara taken for granted. Kapitalisme dianggap benar secara absolut, tanpa pemberian peluang untuk didebat (gair qabil li al-niqasy) dan tanpa kesempatan untuk mengubah (gair qabil li al-tagyir). Lalu ide-ide Kapitalisme itu dijadikan cara pandang (dan hakim) untuk menilai Islam.

\footnotetext{
${ }^{34}$ Husaini dan Hidayat, Islam Liberal, h. 81 \& 131.

${ }^{35}$ Luthfi Asy-Syaukanie (ed.), Wajah Liberal Islam di Indonesia (t.t.p.: Jaringan Islam Liberal, 2002).

${ }^{36} I$ Ibid. h. xxv.

${ }^{37}$ Ibid. h. 30.

${ }^{38}$ Ibid. h. 36.

${ }^{39}$ Ibid. h. 129.

${ }^{40}$ Ibid. h. 135.

${ }^{41}$ Ibid. h.139 \& 142.
} 
Konsep-konsep Islam yang dianggap sesuai dengan Kapitalisme akan diterima, tapi sebaliknya kalau bertentangan dengan Kapitalisme, akan ditolak dengan berbagai dalih. Misalnya penolakan konsep daulah Islâmiyyah, ${ }^{42}$ yang berarti konsep ini dihakimi dan diadili dengan perspektif sekuler yang merupakan pengalaman sempit dan partikular dari Barat. Padahal, sekularisme adalah konsep lokal (Barat), dan tidak bisa dipaksakan secara universal atas dunia selain Barat. Sumartana mengatakan "Apa yang sudah terjadi di Barat sehubungan dengan hubungan antara agama dan negara, sesungguhnya dari awal bercorak lokal dan berlaku terbatas, tidak universal. Prinsip-prinsip yang dilahirkannya bukan pula bisa dianggap sebagai resep mujarab untuk mengobati komplikasi yang terjadi antara negara dan agama di bagian dunia yang lain". ${ }^{43}$

\section{Ancaman Islam Liberal terhadap Pemikiran AhI Sunnah Waljamaah}

Islam Liberal ingin mengusung rasionalisasi dan modernisasi terhadap Islam. Tidak heran golongan ini terjebak dalam memainkan peran akal terlalu bebas, sehingga mereka melabrak prinsip-prinsip pokok dalam Islam. Konsekuensi logisnya, golongan Ahl Sunah Waljamaah merasa terancam dengan kehadiran Islam Liberal, karena ini berkaitan dengan akidah umat Islam sendiri yang akan ternodai. Tetapi, sebagian kalangan umat Islam, dalam memandang gagasan-gagasan kelompok Islam Liberal, masih ada yang cenderung menganggapnya sebagai hal yang absah dalam koridor ikhtilâfyah, yang sangat dihargai dan dijunjung tinggi dalam pemikiran Islam. Padahal, gagasan-gagasan Islam Liberal tidak bias dipandang sebagai masih berada dalam koridor ikhtilâfiyah itu, tetapi telah memasuki wilayah inhirafiyah (penyimpangan) pendapat. ${ }^{44}$ Sebab, landasan berpijak gagasan-gagasan Islam Liberal bukan lagi Islam, tetapi Sekularisme yang notabene merupakan basis ideologi Kapitalisme Barat. ${ }^{45}$

Perlu dijelaskan bahwa pembaharuan dalam Islam memang suatu keharusan dalam rangka menghidupkan ajaran Islam sepanjang masa. Hal ini juga dipicu oleh sifat dan watak Islam yang menghendaki dengan zaman yang dinamis. Tetapi Islam Liberal ini terlalu longgar dalam menafsirkan ajaran Islam, sehingga kebablasan pada ayat-ayat muhkkamât. Padahal pembaharuan dalam Islam adalah usaha untuk menafsirkan kembali ayat-ayat mutasyâbihât bukan muhkkamât serta merubah paham-paham atau ijtihad para ulama masa lalu untuk disesuaikan dengan kemajuan ilmu pengetahuan dan teknologi modern. Artinya, yang diperbaharui dalam Islam adalah bukan ayat-ayat atau hadis,

\section{${ }^{42} I b i d$. h.291.}

${ }^{43}$ Audi, Agama dan Nalar Sekuler, h. xiv. Patut dicatat, sekularisme tidak pernah menjadi konsep yang berlaku di Dunia Islam seperti saat ini, kecuali melalui jalan Imperialisme Barat yang kejam, penuh darah, dan tidak mengenal perikemanusiaan.

${ }^{44}$ Dzulmanni (ed.), Islam Liberal dan Fundamental: Sebuah Pertarungan Wacana, Cet. 6, (Yogyakarta: eLSAQ Press, 2007), h. 238.

${ }^{45}$ Ibid. 
melainkan pemahaman ayat-ayat atau hadis yang ada hubungannya dengan kehidupan di permukaan bumi ini agar sesuai dengan ilmu pengetahuan dan teknologi. Karena itu adalah istilah yang cocok dalam hal ini adalah al-tajdîd fî al-Islâm bukan tajdîd al-Islâm.

Sebagaimana diketahui bahwa al-Qur'an sebagai wahyu Allah (teks Arabnya) bukanlah berasal dari Nabi Muhammad SAW., melainkan seutuhnya dari Allah SWT. Artinya, selain dari teks Arabnya yang berasal dari Allah, tidak dapat disebut dengan wahyu yang bersifat absolut, melainkan adalah hasil pemikiran manusia (ijtihad) yang bersifat relatif. Adapun hadis Nabi Muhammad SAW., berfungsi sebagai penjelas tentang isi al-Qur'an dalam keabsolutan dan kebenaran mutlaknya adalah Hadis Mutawatir yang jumlahnya relatif sedikit.

Perlu dipahami bahwa ayat-ayat al-Qur'an pada umumnya hanya datang dalam bentuk garis-garis besar dan prinsip-prinsip pokok saja tanpa penjelasan lebih lanjut tentang maksud, rincian dan cara pelaksanaannya. Ayat-ayat seperti inilah yang menjadi pegangan umat Islam sejak periode Nabi Muhammad SAW. sampai sekarang bahkan sampai akhir zaman. ${ }^{46}$

Pada masa Rasulullah masih hidup, apabila ada masalah baru atau sesuatu yang belum ada kejelasan hukumnya dalam al-Qur'an, maka para sahabat langsung bertanya kepada beliau. Dalam hal ini, Rasulullah di antaranya menjawab secara langsung dan ada juga ia menyuruh salah seorang sahabat untuk memutuskan perkara tersebut dengan berijtihad di depannya. Cara tersebut, persoalan-persoalan itu dapat dijelaskan dengan baik.

Pada periode sahabat daerah yang dikuasai Islam bertambah luas, sedangkan masalahmasalah baru yang dihadapi muncul semakin menjamur, maka timbullah penafsiranpenafsiran atau penjelasan-penjelasan tentang ajaran Islam yang juga berasal dari ajaranajaran dasar teresbut. Hasil Ijtihad para sahabat ini walaupun tidak maksum seperti Nabi Muhammad SAW., namun ia banyak membawa pengaruh pada zaman sekarang.

Pada masa ulama-ulama besar, daerah Islam semakin luas yang mencakup berbagai bangsa, kebudayan dan adat istiadat. Sejalan dengan berkembang pesatnya daerah Islam tersebut, maka masalah yang dihadapi tentu semakin komplek pula. Padahal, para ulama tidak hidup di satu daerah, melainkan berpencar di daerah-daerah yang berbeda. Konsekuensi logisnya, muncullah penafsiran yang banyak tentang ajaran Islam, baik berbeda satu sama lain, bahkan ada yang bertentangan. Pada periode ini pula penafsiran-penafsiran dari ajaran Islam tersebut mengambil bentuk mazhab-mazhab dan aliran-aliran. Perbedaan penafsiran teresbut tidak hanya antara para mujtahid, tetapi juga terjadi pada diri seorang mujtahid itu sendiri seperti Imam Syâfiî̂ dengan qaul al-qadîm dan qaul al-jadîd. ${ }^{47}$

Dari uraian di atas dapat dilihat bahwa ijtihad para ulama tentang ajaran dasar

${ }^{46}$ Harun Nasution, Teologi Islam, h. 4-5.

${ }^{47}$ M. Hasbi Umar, Nalar Fiqh Kontemporer (Jakarta: Gaung Persada Press, 2007), h. 47. 
dan prinsip-prinsip yang terkandung dalam al-Qur'an terjadi sepanjang masa. Hasil ijtihad akan semakin banyak jumlahnya, bahkan jauh lebih banyak dari ayat-ayat al-Qur'an itu sendiri. Perlu dipahami, karena ijtihad ini hasil pemikiran manusia, maka ia bersifat relatif dan termasuk sebuah kebudayaan. Pemikiran yang dilahirkan Islam Liberal memang termasuk sebuah ijtihad, tetapi prosedur penafsiran yang mereka lalui telah melenceng dari prinsip ajaran Islam. Karena itu, perlu filterisasi atau tindakan preventif terhadap golongan ini supaya tidak terlalu menjalar di tubuh umat Islam. Kalau ini dibiarkan mengakibatkan ancaman yang sangat serius terhadap pemikiran umat Islam.

Sebab itu, langkah yang harus dilakukan sesegera mungkin adalah dengan memantapkan tauhid dan tidak fanatisme (tekstualis) dalam memahami ajaran Islam serta mengadopsi hal-hal yang positif dari pemikiran berat. Artinya sebagai Islam Ahl Sunah Waljamaah berada di posisi antara Fundamentalis dengan Islam Liberalis. ${ }^{48}$

Kalau Islam Fundamentalis yang berpaham kemutlakan Islam jelas bertentangan dengan sifat kedinamisan manusia dan berilmu pengetahuan. ${ }^{49}$ Menurut Muhammad Iqbal, jika manusia bersifat dinamis, maka agama yang berfungsi mengatur hidup manusia tentu harus sesuai pula dengan kedinamikaan manusia. ${ }^{50} \mathrm{Jika}$ tidak demikian, tentu tidak ada kecocokan antara manusia dengan agama, karenanya kemajuan manusia akan terhambat. Maka tidak heran, agama seperti ini akan ditinggalkan manusia. Begitu juga halnya Islam Liberal yang terlalu ekstrim kiri, akan menggiring pemikiran manusia ke arah kebebasan tanpa kendali dan ini akan membahayakan kehidupan manusia.

Golongan Ahl Sunah Waljamaah memahami Islam sebagai agama wahyu yang bersifat dinamis dan rasional. Kedinamisan ini terlihat dari keterbukaannya terhadap unsur-unsur luar selama tidak bertentangan dengan prinsip-prinsip dar dari ajarannya. Karena itulah, pembaharuan dapat terjadi dalam Islam sepanjang masa.

Jadi, dari substansi pemikiran Islam Liberal, setidaknya ada beberapa catatan yang dapat menunjukan kejanggalan dan dapat menngancam pahaman Ahl Sunah Waljamaah:

Pertama, statemen kelompok Islam Liberal mempertuhankan akal di atas segalagalanya. Penyerahan implementasi sepenuhnya nilai-nilai ketuhanan universal kepada kesadaran dan kemampuan akal berarti membangun mekanisme terbalik dalam sistem hukum Islam dengan menempatkan ijtihad di atas kebenaran al-Quran serta keteladanan praktis dari Hadis.

Kedua, Islam Liberal menegaskan hukum-hukum Allah, padahal syariat Allah mencakupi semua aspek, tidak ada satupun di jagat raya ini terlepas dari hukum dan aturan Allah.

\footnotetext{
${ }^{48}$ Bandingkan 'Ali Muhammad al-Shalabî, Khawarij dan Syiah dalam Timbangan Ahl al-Sunnah wa al-Jama 'ah, terj. Masturi Irham \& Malik Supar (Jakarta: Pustaka al-Kautsar, 2007), h. 414.

${ }^{49}$ Q. S. al-Baqarah/2: 31.

${ }^{50} \mathrm{M}$. Iqbal, Pembangunan Kembali Alam Pikiran Islam, terj. Osman Raliby (Jakarta: Bulan Bintang: 1983), h. 176.
} 
Ketiga, Islam Liberal berpendapat semua Agama benar karena dianggap agama tidak lebih dari sebuah proses pencarian nilai kebenaran Ilahi, akan membuat umat ragu dan goncang akidahnya. Statemen ini jelas bertentangan dengan pernyataan Allah bahwa hanya Islam sebagai agama yang diridai-Nya, ${ }^{51}$ dan penegasan Allah bahwa Nabi Muhammad SAW. sebagai penutup para Nabi. ${ }^{52}$

Keempat, sebagai muslim tentu saja sepakat bahwa seorang Nabi dan Rasul tidak perlu dijadikan mitos atau dikultus-individukan, tetapi penghormatan yang tinggi kepada Nabi Muhammad SAW. didasarkan kepada kedudukan beliau yang tinggi dan dibedakan dari manusia lainnya karena segala tindakan dan ucapan beliau selalu terjaga dari dosa. ${ }^{53}$ Karena itu, eksistensi Nabi Muhammad SAW. tidak bisa disejajarkan dengan tokoh sejarah biasa. ${ }^{54}$

Di samping itu, kelompok Islam Liberal juga mengatakan bahwa tidak ada hukum Tuhan dalam pengertian seperti dipahami kebanyakan orang Islam. Misalnya, hukum Tuhan tentang pencurian, jual beli, pernikahan, pemerintahan, dan sebagainya. Pendapat Islam Liberal juga menolak segala bentuk hukuman Tuhan yang dinilai sekedar cerminan budaya Arab. Jilbab, potong tangan, qishâsh, dan rajam, semuanya tidak wajib diikuti karena itu hanya ekspresi lokal partikular Islam di Arab. Bahkan kelompok Islam Liberal mengatakan bahwa hukum Tuhan tidak ada atau nonsense; yang ada adalah seperangkat nilai-nilai Tuhan universal yang implementasinya diserahkan kepada manusia atas dasar konteks sejarah dan sosial..$^{55}$

Ini merefleksikan sebuah reaksi yang cukup "menghebohkan" dari kalangan umat Islam yang tidak dapat menerima pemikiran yang dianggap asing bagi mereka, dan dapat mencederai keyakinan umat Islam yang berpaham Ahl Sunah Waljamaah. Di samping itu, wacana Islam Liberal ini telah mendorong munculnya keyakinan baru bahwa kelompok Islam Liberal ini, sadar atau tidak, telah menjadi bagian integral dari global yang ingin menghancurkan Islam. ${ }^{56}$

${ }^{51}$ Lihat Q. S. Âli 'Imrân/3: 19.

${ }^{52}$ Lihat Q. S. al-Ahzab/33: 40.

${ }^{53}$ Lihat Q. S. al-Najm/53: 2-4.

${ }^{54}$ Sebenarnya bagi kalangan Muslim, kehadiran Islam Liberal tidaklah terlalu ditakuti dan statemen-statemen dari beberapa orang tokohnya, sebenarnya, tidak terlalu penting untuk direspons. Eksistensi mereka hanya ada dalam wacana dan itu hak yang juga harus dihormati. Persoalannya muncul ketika wacana itu telah melampaui batas dengan menegasi, bahkan menghina bagian yang paling peka dalam Islam, yakni konsep tauhid dan pribadi Nabi Muhammad SAW. Lihat Dzulmanni (ed.), Islam Liberal dan Fundamental, h. 214.

${ }^{55}$ Ibid. h. 205.

${ }^{56}$ Q. S. al-Baqarah/2: 120. Dari statemen Islam Liberal, meskipun baru menembus batas wacana, sulit untuk memberikan kesimpulan selain menemukan suatu penghinaan yang nyaris sempurna terhadap Islam. Penghinaan itu telah tersebar kepada publik melalui media dengan penuh kesadaran. Meskipun demikian, statemen-statemen yang pernah dilontarkan oleh kelompok Islam Liberal, cukup berguna untuk menguji kepekaan akidah umat Islam, yang selama ini terus 
Kemudian, pernyataan bahwa "semua agama adalah benar", maka akan menuntut konsekuensi logis bagi penganut keyakinan tersebut untuk memeluk semua agama; agama boleh berpindah-pindah, karena ruh semua agama adalah benar. Dari segi akidah Ahl Sunah Waljamaah, ini jelas bertentangan, argumentasi ini sesuai dengan pernyataan Allah SWT. Dalam al-Qur'an yang maksudnya "katakanlah kepada orang kafir (yang tidak beriman); aku tidak akan menyembah apa yang kamu sembah; dan aku tidak akan jadi penyembah apa yang kamu sembah; sekali lagi aku tidak akan menyembah apa yang kamu sembah; dan tidaklah aku menjadi penyembah apa yang kamu sembah; dan bagimu agamamu dan bagiku agamaku". ${ }^{57}$

Pernyataan Allah tersebut sangat jelas dan tidak akan menimbulkan multi interpretasi. Ayat di atas menjelaskan "semua agama adalah benar menurut keyakinan masing-masing pemeluknya", bukan semuanya benar sebagaimana yang diyakini kelompok Islam Liberal. Jika merujuk kepada Q.S. al-Kâfirûn di atas, maka dapat ditegaskan bahwa Islam itu cukup toleran, karena meskipun berbeda agama, umat Islam tidak dianjurkan bahkan dilarang mencela agama lain dan cukup dengan mengatakan "bagimu agamamu dan bagiku agamaku", dan hubungan sosial tetap berjalan secara damai dan alami, sebagaimana yang dicontohkan Nabi Muhammad SAW.

\section{Penutup}

Dengan demikian, agenda-agenda kelompok Islam Liberal tidak bisa dilepaskan dari Imperialisme Barat atas Dunia Islam. Ide-ide yang diusung kelompok Islam Liberal pun sebenarnya palsu, karena yang ditawarkan adalah Kapitalisme, bukan Islam. Agar laku, lalu diberi label Islam. Islam hanya sekedar simbol, bukan substansi ide kelompok Islam Liberal. Jadi, kelompok Islam Liberal telah menghunus dua pisau yang akan segera ditusukkan ke tubuh umat, agar umat Islam hilang darah (karakter) Islamnya lalu bertaklid buta kepada kelompok Islam Liberal dengan menganut peradaban Barat.

Jika memang dapat dikatakan bahwa kelompok Islam Liberal adalah bagian dari proyek Imperialisme Barat, maka kelompok Islam Liberal sebenarnya mengarah ke jalan buntu. Tidak ada perubahan apapun. Tidak ada transformasi apapun. Sebab yang ada adalah legitimasi terhadap dominasi dan hegemoni Kapitalisme (yang sudah pun berlangsung). Pada saat yang sama, yang ada adalah pementahan dan penjegalan perjuangan umat untuk kembali Islam yang hakiki, terlepas dari hegemoni Kapitalisme. Jadi, mereka telah melanggar prinsip pokok dalam agama. Apabila prinsip ini yang dilanggar mereka telah keluar dari Islam. Karenanya, ajaran seperti ini telah merusak Islam menjadi sebuah ancaman akidah bagi umat Islam lainnya. Pemahaman seperti ini harus diantisipasi

menerus dijejali dengan dakwah akhlak di tengah semaraknya dangdut dan segala bentuk kebid'ahan. Dzulmanni (ed.), Islam Liberal dan Fundamental, h. 214.

${ }^{57}$ Q. S. al-Kâfirûn/109: 1-6. 
dengan cara memantapkan militansi beragama dan kembali kepada tradisi-tradisi Islam Klasik yang cocok dengan zaman sekarang. Sikap umat Islam harus satu, bahwa gagasangagasan Islam Liberal pada dasarnya adalah gagasan-gagasan kufûr yang wajib ditolak karena landasannya adalah Sekularisme yang juga ideologi kufûr, bukan Islam.

\section{Pustaka Acuan}

Abdalla, Ulil Abshar, et. al. Islam Liberal dan Fundamental: Sebuah Pertarungan Wacana, Cet. 6. Yogyakarta: eLSAQ Press, 2007.

Audi, Robert. Agama dan Nalar Sekuler dalam Masyarakat Liberal. Yogyakarta: UII Press, 2002.

Asy-Syaukanie, Luthfi (ed.), Wajah Liberal Islam di Indonesia. t.t.p. Jaringan Islam Liberal, 2002.

Barton, Greg. Gagasan Islam Liberal di Indonesia, terj. Nanang Tahqiq. Jakarta: Paramadina, 1998.

Dzulmanni (ed.). Islam Liberal dan Fundamental: Sebuah Pertarungan Wacana, Cet. 6. Yogyakarta: eLSAQ Press, 2007.

Fyzee, A. A. A. A Modern Approach to Islam. London: Asia Pub. House, 1963.

Husaini, Adian, dan Nuim Hidayat, Islam Liberal Sejarah: Konsepsi, Penyimpangan, dan Jawabannya. Jakarta: Gema Insani Press, 2002.

Iqbal, Muhammad. Pembangunan Kembali Alam Pikiran Islam, terj. Osman Raliby. Jakarta: Bulan Bintang: 1983.

Jabali, Fu'ad. "Telaah Kritis Konsep Aswaja," dalam Luthfi Assyaukanie, Wajah Liberal Islam di Indonesia. Jakarta: Teater Utan Kayu, 2002.

Al-Jawi, Muhammad Shiddiq. "Catatan Kritis Untuk Islam Liberal". Makalah tidak diterbitkan.

Kurzman, Charles. Wacana Islam Liberal: Pemikiran Islam Terkini tentang Isu-Isu Global, terj. Bahrul Ulum. Jakarta: Paramadina, 2001.

Muammar, Khalif. Atas Nama Kebenaran: Telaah Kritis Terhadap Wacana Islam Liberal. Selangor: Akademi Pengajian Tamadun, Universiti Kebangsaan Malaysia, 2001.

Al-Nabhânî, Taqi al-Dîn. Mafâhim Siyâsiyah li Hizb al-Tahrir. t.t.p. Hizb al-Tahrir, 1969.

Al-Nabhânî, Taqi' al-Dîn. Nizhâm al-Islâm, Cet. 6. t.t.p.: Hizb al-Tahrir, 2001.

Nasution, Harun. Teologi Islam: Aliran-Aliran Sejarah Analisa Perbandingan. Jakarta: UI Press, 2002.

Qadir, Zuly, dan Luthfi Assyaukanie. Wajah Liberal Islam di Indonesia. Jakarta: Teater Utan Kayu, 2002.

Umar, M. Hasbi. Nalar Fiqh Kontemporer. Jakarta: Gaung Persada Press, 2007. 
H. A. Kadir Sobur: Islam Liberal dan Ancaman terhadap Pemikiran Ahl Sunah Waljamaah

Al-Shalabî, 'Ali Muhammad. Khawarij dan Syiah dalam Timbangan Ahl al-Sunnah wa alJama 'ah, terj. Masturi Irham \& Malik Supar. Jakarta: Pustaka al-Kautsar, 2007.

Zallum, 'Abd. al-Qadim. Demokrasi Sistem Kufur, terj. Muhammad Shiddiq al-Jawi. Bogor, Pustaka Thariq al-Izzah, 1994.

Zar, Sirajuddin. "Islam dalam Kepemimpinan Indonesia," dalam al-Turas, Oktober 1995Januari 1996. 